\title{
"Więc nie ma żadnej choroby w Wenecji?" Obraz epidemii w noweli Tomasza Manna Śmierć $w$ Wenecji
}

\section{"So There Is No Malady in Venice?" The Image of an Epidemic in Thomas Mann's Short Story Death in Venice}

Abstract: The topic of the paper is the complex image of a cholera epidemic in Thomas Mann's short story Death in Venice. In the first part of the text, devoted to the symbolism of the disease, Asiatic cholera is interpreted as a symbol of human finitude (mortality) and a manifestation of the degeneration of the artist, who, having previously led an ascetic life, falls in love with a teenage boy. Asiatic cholera becomes a symbol of the body rebelling against the mind, which is also reflected on the level of Western culture (reason, discipline) succumbing to Eastern influences (sense, spontaneity). Therefore, Mann's story can be interpreted from the perspective of colonial discourse, according to which the East is perceived as a threat to Europe; in the narrator's view, the source of Asiatic cholera is the climate of India and its poor level of medical knowledge.

In the second part, devoted to human attitudes towards the epidemic, the article presents the local government's policy towards the collective threat; despite the growing number of deaths and infections, the politicians are calming people down, claiming that the situation is completely under control and any sanitary restrictions are introduced as a mere precaution. The reason behind the lie (also repeated by the inhabitants of Venice) is the threat of bankruptcy faced by the people who make their living from tourism. The epidemic is also an opportunity for robberies and even murders, because criminals believe that in these circumstances they will remain unpunished. This pessimistic image suggests that humans are egoistic and care more about their own fate than the fate of others when standing in the face of danger.

Keywords: Venice, Asiatic cholera, epidemic, art, death

Streszczenie: Tematem artykułu jest złożony obraz epidemii cholery w noweli Tomasza Manna Śmierć $w$ Wenecji. W części pierwszej, poświęconej symbolice zarazy, indyjska cholera została zinterpretowana jako znak ludzkiej skończoności (śmiertelności) oraz 
przejaw degeneracji artysty, który - prowadząc wcześniej ascetyczny tryb życia - zakochał się w kilkunastoletnim chłopcu. W ten sposób indyjska cholera staje się symbolem buntu ciała przeciwko duchowi, co znajduje także swoje odzwierciedlenie na płaszczyźnie kultury zachodniej (rozum, dyscyplina), ulegającej wpływom wschodnim (zmysły, żywiołowość). W jakiejś zatem mierze nowelę Manna można odczytywać w duchu dyskursu kolonialnego, zgodnie z którym Wschód jest postrzegany jako zagrożenie dla Europy; w ocenie narratora bowiem źródłami indyjskiej cholery są klimat oraz niski poziom medycyny w Indiach.

W części drugiej, poświęconej postawom ludzi wobec epidemii, ukazana została polityka władz miasta wobec zbiorowego zagrożenia; pomimo coraz większej liczby zgonów i zachorowań politycy uspokajają mieszkańców, że sytuacja jest pod kontrolą, a rygory higieniczne wynikają z ostrożności. Powodem takiego kłamstwa (powtarzanego także przez mieszkańców Wenecji) jest groźba bankructwa ludzi żyjących z turystyki. Panująca epidemia jest też okazją do napadów rabunkowych, a nawet morderstw, przestępcy wierzą bowiem, że w zaistniałych okolicznościach pozostaną bezkarni. Obraz ten sugeruje, że człowiek jest istotą egoistyczną, w warunkach zagrożenia bardziej troszczącą się o własny los aniżeli o los innych ludzi.

Słowa kluczowe: Wenecja, indyjska cholera, epidemia, sztuka, śmierć

\section{Wstęp}

Wenecja to jedno z najbardziej symbolicznych miast świata, w wypadku którego trudno oddzielić mit od rzeczywistości. Nawiedzana przez powodzie bywa też ofiarą epidemii, których źródłem są zarówno klimat, jak i turystyka. W czasie słynnej epidemii dżumy w latach 1347-1348 w mieście zmarła ponad połowa mieszkańców ${ }^{1}$. W roku 1911 Wenecję nawiedziła indyjska cholera, o której wspomina Tomasz Mann w noweli Śmierć $w$ Wenecji². Sukces utworu sprawił, że główny bohater, Gustav von Aschenbach, stał się bardziej rozpoznawalnym symbolem Wenecji niż wiele historycznych postaci z nią wiązanych. Jedną z ikon miasta zbudowanego na lagunie jest Marco Polo, którego dzieło Opisanie świata (wydane około roku 1298) jest relacją z podróży do wielu wschodnich krain (zwłaszcza do państwa Wielkiego Chana) ${ }^{3}$. Innym symbolem Wenecji jest Tintoretto, który w swoich obrazach portretował zarówno jej architekturę, jak i życie społeczne. Ważnym motywem jego malarstwa była woda jako symbol ludzkiej duszy - raz spokojnej i cichej, innym razem gwałtownej i wzburzonej; Tintoretto był też autorem gigantycznych malowideł w Pałacu Dożów ${ }^{4}$.

1 Por. W. Naphy, A. Spicer, Czarna śmierć, tłum. A. Dębska, Warszawa 2004, s. 22-23.

2 Por. T. Mann, Śmierć $w$ Wenecji, tłum. L. Staff [w:] tegoż, Śmierć $w$ Wenecji $i$ inne opowiadania, Wrocław 2003, s. 135-188. Nowelę cytuję przez podanie numeru stronicy. Korzystam też z oryginału: tenże, Der Tod in Venedig [w:] tegoż, Erzählungen, Leipzig 1984, s. 190-262.

3 Por. K. Żaboklicki, Historia literatury wtoskiej, Warszawa 2019, s. 31.

4 Por. P. Ackroyd, Wenecja. Biografia, tłum. T. Bieroń, Poznań 2015, s. 42, 122-123, 228; P. Muratow, Obrazy Wtoch, tłum. P. Hertz, Warszawa 1972, t. 1, s. 25. 
Z pewnością szerzej znany jest libertyn Giacomo Casanova, uchodzący za symbol Wenecji jako miasta rozpusty; do dziś powtarzana jest legenda, według której słynny kochanek odradza się w każdym dziecku urodzonym na lagunies. Miłośnikom muzyki Wenecja kojarzy się z Antoniem Vivaldim, dzięki któremu miasto uchodziło za stolicę opery ${ }^{6}$. Miasto na lagunie było też bliskie Byronowi, który zamieszkał w nim po opuszczeniu na zawsze kraju rodzinnego ${ }^{7}$; poeta uważał Wenecję za miejsce wyjątkowo sprzyjające twórczości artystycznej, ponieważ - w przeciwieństwie do Anglii, gdzie panuje szarość i mgła - jest krainą słońca i radości istnienia. Zdaniem George’a Byrona Wenecja miała też wzorcowy ustrój polityczny, harmonijnie godzący wpływy arystokracji z rządami ludu. Jeszcze ściślej z Wenecją związane były losy Ryszarda Wagnera, który przybył na lagunę w roku 1858, w czasie kryzysu małżeńskiego, wywołanego jego romansem z Mathilde Wesdonk. Pobyt okazał się nieudany z powodu dezynterii oraz koszmarnych snów, jakie nawiedzały kompozytora; mimo to napisał wówczas drugi akt Tristana i Izoldy ${ }^{9}$. Nie mogąc kontaktować się z kochanka, spisywał swoje uczucia w Dzienniku weneckim; pogorszenie stanu zdrowia i kłopoty z policją zmusiły go w następnym roku do wyjazdu ${ }^{10}$. Ostatni raz Wagner przybył do Wenecji we wrześniu 1882 roku, gdzie pozostał do śmierci, która nastąpiła 13 lutego 1883 roku; kompozytor zmarł w wyniku ataku serca w ramionach swojej ówczesnej żony Cosimy ${ }^{11}$. Nie ma wątpliwości, że do czasu publikacji noweli Manna była to najsłynniejsza z weneckich śmierci; przyćmił ją dopiero zgon Aschenbacha. Ten literacki mit „śmierci w Wenecji” okazał się na tyle trwały, że coraz częściej pojawiają się głosy postulujące stworzenie nowej symboliki, która zastąpiłaby wizję Manna; autorem najbardziej radykalnego poglądu był Massimo Cacciari, mer Wenecji w latach 1993-2000 oraz 2005-2010, głoszący hasło „zapomnieć Manna” ${ }^{12}$. Powodem jest to, że nowela Manna uchodzi za kulminację historycznego mitu Wenecji jako miasta śmierci - zarówno tego, w którym najlepiej umrzeć, jak i tego, które samo umiera (z racji kruchości murów, podmywanych przez wodę); politykom marzy się jednak nowy mit miasta, który będzie budował jej przyszłośćc ${ }^{13}$.

5 Por. P. Ackroyd, dz. cyt., s. 13, 95.

6 Por. tamże, s. 381-387.

7 Por. G. Sampson, Historia literatury angielskiej w zarysie, Warszawa 1967, s. 696.

8 Por. T. Turner, Venice Desired, Cambridge, Massachusetts 1992, s. 51-53.

9 Por. W.H. McClain, Wagnerian Overtones In „Der Tod in Venedig”, „Modern Language Notes" 1964, vol. 79, nr 5, s. 482-484.

10 Por. B. Millington, Kalendarium życia Wagnera, jego dziet i wydarzeń, tłum. R. Monita [w:] Wagner. Kompendium. Przewodnik po życiu i twórczości kompozytora, red. B. Millington, Kraków 2014, s. 14.

11 Por. tamże, s. 20.

12 Por. X. Tabet, Venise dans la littérature française du XX siècle, „Laboratoire Italien” 2014, nr 15, s. 250-251.

13 Por. M. Bordry, Venise, ville morte ou „capitale di XIX siècle”? Regards vènitiens sur la disparition de la culture vènitienne, „Postures. Revue - critique littéraire” 2017, nr 26, http://revuepostures.com/fr/articles/bordry-26, dostęp: 27.08.2020. 
Śmierć $w$ Wenecji zawiera wiele rysów autobiograficznych, co potwierdzali zarówno żona pisarza, $\mathrm{Katia}^{14}$, jak i sam autor, wyznając, że w utworze „nic nie zostało zmyślone"15. Mann opisał w noweli swoją miłość do nastolatka z Polski, którego spotkał w Wenecji; chłopcem tym był - pochodzący z rodziny arystokratycznej - Władysław Moes ${ }^{16}$. Mannowie przybyli na lagunę w maju 1911 roku wraz z bratem Tomasza - Henrykiem; zamieszkali na wyspie Brioni ${ }^{17}$, znanej z medycznych prac Roberta Kocha, które doprowadziły do zwalczenia ognisk malarii i cholery ${ }^{18}$. W czasie pobytu Mannów na lagunie wybuchła epidemia indyjskiej cholery, zatajana przez władze. Wprawdzie akcja noweli nie ma dokładnej daty, to jednak można ją w przybliżeniu ustalić na czas pobytu Mannów na lagunie ${ }^{19}$; potwierdzeniem może być to, że utwór został ukończony i opublikowany w roku 1912, narrator zaś umiejscawia wydarzenia w roku 19 ... (s. 137).

Fabuła noweli jest prosta: mieszkający w Monachium pisarz Gustav von Aschenbach, od lat będący wdowcem i ojcem dorosłej córki, postanowił udać się na wypoczynek. Po załatwieniu najpilniejszych spraw wyjechał na wyspę Poli („piekło”); ponieważ jednak źle znosił towarzystwo hotelowe, przeniósł się do Wenecji. Tu spotkał Tadzia, pięknego chłopca z Polski, zakochując się w nim od pierwszego wejrzenia. Początkowo widział w nim uosobienie naturalnego piękna, z czasem jednak uczucie nabrało także wymiaru erotycznego. Wprawdzie nie zamienił z chłopcem ani słowa, nigdy go też nie dotknął, to jednak pragnął przebywać w jego towarzystwie; rojąc o odwzajemnieniu uczucia, odmłodził nawet swój wygląd. Trapiony kłopotami zdrowotnymi odkrył, że w Wenecji panuje epidemia cholery, która wybuchła jeszcze przed jego przyjazdem; mimo zagrożenia nie opuścił miasta, chcąc przebywać w pobliżu Tadzia. W dniu wyjazdu polskiej rodziny zmarł, zapatrzony w chłopca.

$\mathrm{Na}$ pierwszy rzut oka wydaje się, że Aschenbach był ofiarą epidemii ${ }^{20}$, jednak przyczyna zgonu nie jest pewna, narrator bowiem nie daje jednoznacznej odpowiedzi na pytanie, z jakiego powodu umarł bohater. Już w pierwszych

14 Por. K. Mann, Moje nienapisane wspomnienia, przyg. E. Plessen, M. Mann, tłum. E. Bielicka, Warszawa 2007, s. 63.

15 Por. M. Wołk, Gtosy labiryntu. Od „Śmierci w Wenecji” do „Monizy Clavier”, Toruń 2009, s. 40, przypis 16 .

16 Por. G. Adair, The Real Tadzio: Thomas Mann's Death in Venice and the Boy, who Inspired It, New York 2013, s. 12-21.

17 Por. E.M. Wolf, A Case of Slightly Mistaken Identity: Gustav Mahler and Gustav Aschenbach, „Twentieth Century Literature” 1973, t. 19, nr 1, s. 41.

18 Por. A. Ghosh, The Horror of Contact: Understanding Cholera in Mann's „Death in Venice”, „Transtext(e)s Transcultures. Journal of Global Cultural Studies” 2017, nr 12, s. 2. Koch był odkrywcą bakterii wywołujących cholerę. Por. S. Sontag, AIDS and Its Metaphors [w:] tejże, Illness as Metaphor and AIDS and Its Metaphors, New York 1990, s. 130.

19 Por. W. Leppmann, Time and Place in "Death in Venice”, „The German Quarterly” 1975, t. 48, nr 1, s. 71-73.

20 Por. A. Ghosh, dz. cyt., s. 1, 5. 
dniach pobytu na lagunie Aschenbach poczuł się źle (co w Wenecji zdarzyło mu się też wcześniej), nie wyjechał jednak, ponieważ jego bagaż wysłano na błędny adres (s. 162). Możliwe zatem, że powodem śmierci była reakcja organizmu na wilgotny klimat; mogło nim być także zatrucie przejrzałymi poziomkami, kupionymi na straganie (s. 185). Potwierdzeniem takiej interpretacji jest to, że bezpośrednią przyczyną cholery indyjskiej są bakterie, które dostają się do żołądka, najczęściej z pokarmem ${ }^{21}$. Również miejsce śmierci bohatera nie jest pewne, ponieważ zasłabł na plaży i został przeniesiony do hotelu; dopiero wtedy poinformowano o jego zgonie (s. 188).

Pomimo niejasnej przyczyny śmierci Aschenbacha można uznać za ofiarę epidemii, zmarł bowiem w czasie jej trwania i miał niektóre objawy cholery (duszność, pragnienie) ${ }^{22}$. Epidemia jednak, podobnie jak inne elementy fabuty (spotkanie cudzoziemca na spacerze, zaloty obleśnego starca na statku, podróż gondolą z przewoźnikiem bez licencji czy występ muzykantów w hotelu), ma nie tylko sens dosłowny, lecz także symboliczny ${ }^{23}$. $Z$ tego powodu w pierwszej części artykułu zinterpretuję indyjską cholerę jako metaforę ludzkiego losu i europejskiej kultury²4; w części drugiej opiszę postawy ludzi wobec epidemii.

\section{Symbolika zarazy}

Symbolika noweli Manna dopuszcza różne odczytania ${ }^{25}$; dotyczy to również epidemii cholery, którą można interpretować jako znak ludzkiej skończoności (1), świadectwo słabości ducha (2), symbol moralnego upadku Aschenbacha (3), przejaw kryzysu europejskiej kultury (4), a nawet wyraz kolonializmu (5).

21 Por. M. Ostaszewski, Pamięć o epidemii cholery z 1893 roku we wsi Bagnówka pod Biatymstokiem, „Studia Podlaskie” 2015, t. 23, s. 121.

$22 \mathrm{Na}$ temat możliwych przyczyn śmierci Aschenbacha por. P. Kitcher, Deaths in Venice: The Cases of Gustav von Aschenbach, New York 2013.

23 Bogactwo odczytań poszczególnych aspektów noweli jest olbrzymie; ich przegląd zawierają prace: E. Shookman, Thomas Mann's Death in Venice: A Novella and Its Critics, Camden House 2003; tenże, Thomas Mann's Death in Venice: A Reference Guide, Greenwood 2004.

24 Choroba rozumiana jako zjawisko kulturowe jest nie tylko rzeczywistością przeżywaną przez człowieka, lecz także nośną metaforą, wskazującą na ludzką kondycję. Metaforyzacja choroby jednak utrudnia dostrzeżenie w niej zjawiska czysto medycznego. Por. S. Sontag, AIDS and Its Metaphors, dz. cyt., s. 102.

25 Por. M.V. Llosa, Wotanie z otchtani [w:] M.V. Llosa, Prawda ktamstw. Eseje o literaturze, tłum. D. Walasek-Elbanowska, Poznań 1999, s. 19. 


\section{1. „Ulicami tajemniczo snuła się ohydna śmierć”}

Skupieni na codziennych zadaniach rzadko uwzględniamy możliwość własnej śmierci, wykluczającej realizację powziętych planów; chociaż bowiem inni ludzie umierają, to jednak ja ciągle żyję, jakbym był nieśmiertelny ${ }^{26}$. Epidemia tę optykę zmienia, oznacza bowiem, że ja też mogę umrzeć; śmierć staje się w ten sposób nie tylko powszechna, lecz także bliska (a nawet nieuchronna). Świadomość własnej skończoności przestaje być prawdą abstrakcyjną, stając się przedmiotem doświadczenia; potwierdzeniem jest wyludniająca się Wenecja, po której snuje się wszechobecna śmierć (s. 183) ${ }^{27}$. O zagrożeniu świadczy również pustoszejący hotel Aschenbacha, pomimo pełni sezonu turystycznego (s. 171); powodem są masowe wyjazdy z zakażonego miasta, sugerujące, że (w rezultacie epidemii) ludzie ponownie odkryli własną śmiertelność nie tyle jako abstrakcyjne pojęcie, ile żywą i doniosłą prawdę egzystencjalną. W późniejszej powieści Manna Czarodziejska góra, której akcja toczy się w sanatorium dla chorych na gruźlicę, pusty pokój nie oznaczał wyjazdu ani wyzdrowienia, lecz śmierć. Choroba tocząca pensjonariuszy zapowiada jednocześnie masowy kataklizm, którym była pierwsza wojna światowa. Główny bohater, Hans Castorp, po siedmiu latach spędzonych w uzdrowisku udał się na front, na którym prawdopodobnie zginie:

Złe masz widoki na przyszłość, straszliwy tan, który cię porwał, potrwa jeszcze dobrych parę latek i nie założylibyśmy się, czy wyjdziesz z tego cało. Szczerze mówiąc, pozostawiamy beztrosko kwestię tę otwartą. Przygody cielesne i duchowe wzbogaciły twą prostoduszność i pozwoliły ci duchem przetrwać czas, którego zapewne nie przetrwasz ciałem ${ }^{28}$.

Podobnie epidemię cholery w Wenecji można zinterpretować w duchu grożącego Europie kataklizmu wojennego; przede wszystkim wskazuje ona na ludzką skończoność. Zarówno w Davos, jak i w Wenecji, mimo powszechnej obecności śmierci, ludzie w nią nie wierzą; bohaterowie Czarodziejskiej góry mają nadzieję na wyzdrowienie, natomiast mieszkańcy i władze Wenecji nie informują o zarazie, aby nie wypłoszyć turystów.

Indyjska cholera staje się w ten sposób symbolem ludzkiego losu, a nowela Manna - ilustracją wschodniej legendy o człowieku, który zobaczył w swym ogrodzie śmierć; przerażony uciekł po to tylko, by jeszcze tego samego dnia

26 Por. V. Jankélélevitch, La mort, Paris 2008, s. 10.

27 Zob. „Tod alles störende Leben in der Runde entfernen”. T. Mann, Der Tod in Venedig, dz. cyt., s. 256.

28 Tenże, Czarodziejska góra, t. 2, tłum. J. Łukowski, Warszawa 1972, s. 536. 
umrzeć w miejscu od zawsze sobie przeznaczonym ${ }^{29}$. Historia Aschenbacha jest podobna; spotkawszy na spacerze nieznajomego wędrowca, postanowił wyjechać z Monachium. Początkowo zatrzymał się na wyspie Poli, po czym przeniósł się do Wenecji, gdzie zmarł. Nawet próba wyjazdu nie uchroniła go przed śmiercią; skoro bowiem zgubiono jego bagaż, postanowił zostać, ciesząc się dalej widokiem Tadzia. Wprawdzie każde z tych zdarzeń jest przypadkowe, jednak wzięte razem wskazują na nieuchronność śmierci Aschenbacha ${ }^{30}$; jego historię można zatem odczytać w duchu greckiej idei losu, którego nikt nie uniknie. Nowela obrazuje zatem skończoność człowieka - nawet jeśli okoliczności śmierci są przypadkowe, to śmiertelność jest wpisana w ludzką naturę.

Masowość śmierci powoduje, że trudno mówić o wyjątkowości, a nawet indywidualności tego, kto umiera; zmarły w czasie epidemii powiększa jedynie ogólną liczbę ofiar. Jednocześnie choroba stygmatyzuje człowieka, który staje się zagrożeniem dla innych; to zaś, że nie ustrzegł się infekcji, uchodzi za winę lub nieostrożność. Los Aschenbacha jest zatem odmienny od losu Hansa Castorpa. Bohater Czarodziejskiej góry był wszak chory na gruźlicę, która oznaczała nobilitację. Odkąd okazało się, że ma plamy na płucach, poczuł się pełnowartościowym mieszkańcem sanatorium; nie był już przybyszem z nizin, odwiedzającym chorego kuzyna, lecz osobą wtajemniczoną w misterium życia i śmierci ${ }^{31}$. Gruźlica stawia też Castorpa w uprzywilejowanej pozycji poznawczej - dzięki chorobie wyzbył się trywialnych pojęć, zyskując wrażliwość poety pytającego o sens istnienia.

Los Aschenbacha jest odwrotny, pisarz uległ bowiem depersonalizacji przez to, że umarł w czasie epidemii, powiększając liczbę ofiar; masowa śmierć pozbawia go wyjątkowości, a nawet indywidualności ${ }^{32}$. Artyści tymczasem, jak ironizował Mann, nie chcą umierać tłumnie; uważając się za geniuszy, pragną śmierci, która będzie indywidualnym przejściem do wieczności - przynajmniej w sensie trwałej obecności w kulturze ${ }^{33}$. Tymczasem śmierć Aschenbacha, jeśli nawet świat przyjął ją z respektem (s. 188), w zakażonej Wenecji nie była niczym wyjątkowym.

Anonimowość pisarza była już zresztą widoczna wcześniej; pomimo kontaktów z wieloma osobami (kelnerzy, podróżni na statku, goście hotelowi, przechodnie) nie spotkał nikogo, kto znałby jego książki. Wtopiony w rzeszę turystów stał się (jak każdy) potencjalną ofiarą epidemii; nawet pracownik biura

29 Por. M. Szyrocki, Literatura niemieckiego obszaru jezykowego [w:] Dzieje literatur europejskich, red. W. Floryan, Warszawa 1982, t. 2, cz. 1, s. 144.

30 Można powiedzieć, że opozycja między przypadkiem a predestynacją została w noweli zawieszona. Por. M. Wołk, dz. cyt., s. 44.

31 Gruźlica nobilituje Castorpa, nadając mu indywidualność i podmiotowość. Por. S. Sontag, Illness as Metaphor [w:] tejże, Illness as Metaphor and AIDS and Its Metaphors, dz. cyt., s. 37.

32 Por. tamże.

33 Por. T. Mann, Jak powstat Doktor Faustus. Powieść o powieści, tłum. M. Kurecka, Warszawa 1960, s. 111. 
turystycznego, radzący mu wyjechać, nie wiedział, z kim rozmawia. Turystyka bowiem, podobnie jak śmierć, jest masowa, odbiera ludziom wyjątkowość. Los Aschenbacha świadczy zatem, że rodzimy się, żyjemy i umieramy jako bezimienni uczestnicy tej samej natury; epidemia tylko tę prawdę ujawnia.

\section{2. „Obcy bóg!”}

Zaraza symbolizuje nie tylko śmiertelność człowieka, lecz także słabość jego ducha; wprawdzie Aschenbach żył dotąd jedynie sztuką, to jednak na lagunie odkrył, że jest również narażonym na upadki ciałem. Paradoksalnie właśnie owo kruche ciało, podatne na infekcje i choroby, okazuje się warunkiem twórczości. Z punktu widzenia artysty sytuacja ta wydaje się absurdalna, trudno wszak pogodzić się z faktem, że twórczy duch zależy od kaprysów ciała. Podobnym absurdem jest to, że poszukujący odpoczynku pisarz, będący intelektualnym i moralnym autorytetem, trafia do miasta, w którym panuje zaraza. Sytuacja ta sprawia wrażenie szczególnej ironii losu, Aschenbach bowiem całe życie poświęcił sztuce, swoim organizmem zajmując się tylko w takim stopniu, w jakim było to niezbędne do pracy literackiej ${ }^{34}$. Z tego powodu przypadkowa śmierć w czasie epidemii może się wydawać ponurym żartem ${ }^{35}$.

Zależność ducha od ciała ma też wymiar dodatkowy, związany z tłumionymi przez Aschenbacha skłonnościami erotycznymi. Żyjąc tylko dla sztuki, ignorował potrzeby zmysłów, jednak z chwilą ujrzenia Tadzia mechanizmy obronne przestały działać. Od tej pory, sztubacko zakochany w nastolatku, oddał się orgii uczucia; artystyczną i moralną dyscyplinę zastąpiła nieokiełznana potęga instynktów. Jak zatem epidemia wywołała społeczny chaos w Wenecji, tak miłość zburzyła życiowy ład Aschenbacha; zarówno miłość, jak i cholera są jednak czynnikami niezależnymi od ludzkiej woli ${ }^{36}$, dzięki czemu epidemia może symbolizować upadek pisarza, którego zmysłowość wymknęła się spod kontroli. „Epidemia obrazuje (...) cenę zwyrodnienia, szaleństwa i ruiny, jaką być może będzie musiał zapłacić ten, kto ulega pokusom rozpaczy i poddaje swój intelekt irracjonalnemu dyktatowi namiętności” ${ }^{37}$. Moc ducha okazuje się iluzją, pozostaje on bowiem w niewoli ciała ${ }^{38}$. Ulegając potędze erosa, którego przejawem był orgiastyczny sen (s. 182-183), Aschenbach przestał być arty-

34 Jak ironicznie pisał Mann, nawet posiłki i sen Aschenbacha służyły jedynie sztuce (s. 168).

35 Równie absurdalna była śmierć Tomasza Buddenbrooka, który zmarł po wizycie u dentysty; zawsze nienagannie ubrany i przestrzegający reguł etykiety upadł po wyjściu z gabinetu w pośniegowe błoto. „Jak on wyglądał (...), kiedy go przynieśli! Jak długo żył, nie widziało się na nim pyłka... to jest hańba i podłość, żeby taki musiał być koniec!...”. T. Mann, Buddenbrookowie. Dzieje upadku rodziny, tłum. E. Librowiczowa, Warszawa 1956, s. 619.

36 Por. M. Wołk, dz. cyt., s. 51.

37 M.V. Llosa, dz. cyt., s. 23.

38 Por. tamże, s. 22. 
stą, zdolnym przekuć namiętności w dzieło sztuki; Apollin uległ zatem potędze Dionizosa, co spowodowało destrukcję twórczej osobowości pisarza. Zamiast dotychczasowego ładu intelektualnego i moralnego, w jego życiu zapanował chaos, którego symbolem jest epidemia. Potwierdzeniem takiej interpretacji może być nazwisko bohatera, „Asche” wszak to popiół (także prochy zmarłych), natomiast „Bach” to strumień, potok. Połączenie obu słów może sugerować, że zarazki (,pyłki”) cholery dotarły do Wenecji morzem i utrzymują się w kanałach $^{39}$. Dodatkowym argumentem jest obecna w tle noweli postać boga Dionizosa, uchodzącego za bóstwo obszarów wilgotnych i bagiennych ${ }^{40}$. W swoich podróżach dotarł on także do Indii ${ }^{41}$, a jego właściwą porą była wiosna, kiedy to rozpoczyna się akcja noweli ${ }^{42}$. W połowie maja, jeszcze przed przyjazdem Aschenbacha, „w Wenecji znaleziono jednego i tego samego dnia straszne wibriony w wyniszczonych i sczerniałych trupach chłopca okrętowego i zieleniarki. Ale wypadki te zatajono. Ale po tygodniu było ich dziesięć, było dwadzieścia, trzydzieści, i to w różnych dzielnicach" (s. 180). Szybkie tempo rozszerzania się zarazy przypomina chorobliwą dzikość i żywiołowość antycznych kultów dionizyjskich, niosących ze sobą fizyczne i duchowe okaleczenia ${ }^{43}$. Indyjska cholera obrazuje w ten sposób destrukcję artysty, który stracił kontrolę nad sobą; poddany władzy obcego boga zapłonął nieokiełznanym żarem namiętności (s. 182-183).

39 Nazwisko bohatera („potok popiołów”) można też odczytać jako symbol spopielenia się w żarze namiętności. Por. M. Wołk, dz. cyt., s. 43.

40 Słowo „bagno” („Sumpf”) pojawia się w rozmyślaniach Aschenbacha, planującego poinformować matkę Tadzia o zarazie. „Mógłby wtedy narzędziu szyderczego bóstwa na pożegnanie położyć rękę na głowie, odwrócić się i uciec temu bagnu” (s. 181-182). „Er konnte dann dem Werkzeug einer höhnischen Gottheit zum Abschied die Hand aufs Haupt legen, sich wegwenden und diesem Sumpfe entfliehen" (s. 253). Bagno oznacza zarówno położenie Wenecji i jej klimat, jak i upadek moralny Aschenbacha; tylko rychły wyjazd mógłby uratować pisarza.

41 Por. P. Grimmal, Stownik mitologii greckiej i rzymskiej, tłum. M. Bronarska, B. Górska, A. Nikliborc, J. Sachse, O. Szarska, Wrocław 1990, s. 74-75.

42 Por. T.-Z. Kim, Funkcje mityczne we wczesnych utworach Tomasza Manna, tłum. B. Tarnas [w:] Tomasz Mann w oczach krytyki światowej, wyb. A. Rogalski, Warszawa 1975, s. 110-111. Warto w tym miejscu odnotować, że w tłumaczeniu Leopolda Staffa Aschenbach wybrał się na spacer „w letnie popołudnie” (s. 137), podczas gdy Mann pisze o wiosennym popołudniu „(Frühlingsnachmittag”) (s. 190). Była to jednak wyjątkowa pora, kiedy to po zimnych i wilgotnych tygodniach „nastała złudna pełnia lata” (s. 137); „ein falscher Hochsommer eingafallen" (s. 190).

43 Rozprzestrzenianie się kultu Dionizosa przypominało w starożytnej Grecji „religijną epidemię". Por. E. Rhode, Psyche. Kult duszy i wiara w nieśmiertelność u starożytnych Greków, wyb. H. Eckstein, tłum. J. Korpanty, Kęty 2007, s. 170-218. 


\section{3. „Teraz może pan zakochać się spokojnie”}

Przejawem upadku Aschenbacha była nagła i niekontrolowana miłość do Tadzia. Chłopiec zwrócił na siebie uwagę pisarza tym, że był niewypowiedzianie piękny (s. 171), ale zauroczenie estetyczne nabrało cech erotycznych ${ }^{44}$. Zakochany pisarz porzucił literaturę, szukając jedynie sposobności do oglądania chłopca; podążał za nim po całej Wenecji, w myślach wyznając mu miłość (s. 171-173). Wprawdzie początkowo zachwyt nad pięknem Tadzia zainspirował Aschenbacha do napisania krótkiej rozprawki, będącej fragmentem „wytwornej prozy, której czystość, szlachetność i lotne uczuciowe napięcie niebawem miały budzić podziw ludzi” (s. 167), była to jednak tylko chwilowa sublimacja popędu, który z czasem bez reszty owładnął pisarzem.

Jest rzeczą niewątpliwie dobrą, że świat zna tylko piękne dzieło, nie zaś jego pobudki, okoliczności jego powstania; gdyż znajomość źródeł, z których spłynął na artystę pomysł, wprawiłaby go w kłopot, odstraszyłaby go i przez to unicestwiła działanie tego, co doskonałe (s. 167).

Aschenbach zdawał sobie sprawę z niestosowności swego zachowania, zwłaszcza że w wyznawanej przez niego mieszczańskiej etyce nie toleruje się łamania norm obyczaju. Dodatkowym problemem jest to, że obiektem miłości był chłopiec, którego wiek narrator szacował na lat czternaście (s. 153) ${ }^{45}$. Mamy zatem do czynienia ze skłonnością pośrednią między homoerotyzmem a pedofilią w epoce, w której homoerotyzm uchodził za przestępstwo (a przynajmniej chorobę), pedofilia zaś nie była jeszcze pojęciowo i prawnie wyodrębniona ${ }^{46}$. W prawdzie miłość do młodych chłopców była ewidentną cechą antycznej kultury greckiej, o czym dobitnie świadczą dialogi Platona, to jednak była też postrzegana jako obyczaj przywieziony ze Wschodu. Przy takiej interpretacji epidemia panująca w Wenecji byłaby metaforą upadku Aschenbacha (s. 175), którego europejska dusza (s. 139) została zatruta orientalnym

44 „W chłopcu ujrzanym na weneckiej plaży widzi zrazu nie istotę z krwi i kości, lecz odblask samej idei piękna. Uwiedziony przez formę, »skończone« i pozornie bezcielesne piękno Tadzia stopniowo ulega pożądaniu, zatraca się w nim”. M. Wołk, dz. cyt., s. 52.

45 Rzeczywisty Tadzio (Władysław Moes), w którym zakochał się Mann, miał niespełna lat 11. Por. G. Adair, dz. cyt., s. 18-19. Nie ma jednak wątpliwości, że podobieństwo Manna i Aschenbacha polega na miłości do pięknych chłopców. Por. K. Mann, dz. cyt., s. 66. Dzienniki Manna sugerują, że przynajmniej raz spojrzał na swego pięcioletniego syna Klausa tak, jak Aschenbach patrzy na Tadzia. Por. M. Krüll, Im Netz der Zauberer: Eine andere Geschichte der Familie Mann, Zurich 1991; cyt. za: E. Shookman, Thomas Mann's „Death in Venice”: A Novella and Its Critics, dz. cyt., s. 198.

46 Mann podpisał petycję przeciw penalizacji homoseksualizmu w niemieckim prawie. Por. W. Lederer, Love in Society: Thomas Mann's Early Stories [w:] A Companion to the Works of Thomas Mann, red. H. Lehnert, E. Wessell, Camden House 2004, s. 91, przypis 21. 
grzechem. Indyjska cholera byłaby zatem nie tyle zakaźną chorobą, ile stanem umysłu pisarza, który nie potrafi wyzwolić się z namiętności ${ }^{47}$.

W metaforze epidemii jako upadku ważne jest też to, że miłość Aschenbacha zrodziła się w Wenecji, która od wieków uchodziła za miasto rozpusty i niejednoznacznych postaw erotycznych ${ }^{48}$; na przełomie XIX i XX wieku była jednym z miejsc, do którego chętnie przybywali niemieccy geje ${ }^{49}$. Przyjazd Aschenbacha można byłoby w tym kontekście uznać za seksualną turystykę, tym bardziej że pisarz zwrócił uwagę na Tadzia już pierwszego dnia (s. 153), starając się odtąd przebywać w jego pobliżu. Podobnie fakt, że Aschenbach nie odwiedza muzeów ani galerii weneckich, może świadczyć, że przybył na lagunę raczej w celach erotycznych niż artystycznych. Zachowanie to może potwierdzać interpretację epidemii jako metafory upadku pisarza, co zresztą sugeruje sam bohater, dostrzegając paralelę między cholerą a swoją miłością do Tadzia (s. 175):

poszukiwał oparcia, by ustrzec swą godność. Ale zarazem zwracał ustawicznie czujną i uporczywą uwagę na nieczyste zdarzenia w łonie Wenecji, na ową przygodę świata zewnętrznego, która spływała się niejasno z przygodą jego serca i żywiła jego namiętność nieokreślonymi, bezprawnymi nadziejami (s. 175).

O ile jednak Tadzio opuszcza Wenecję „niewinny i nieskalany”, o tyle „Aschenbach staje się moralnym i fizycznym wrakiem” ${ }^{50}$. Podobieństwo widać również w literackim sposobie przedstawienia obu zjawisk, Mann opisuje bowiem miłość Aschenbacha jako spustoszenie duchowe, analogiczne do śmiertelnego żniwa zebranego w Wenecji przez cholerę ${ }^{51}$. Tak samo zresztą, jak

47 Podobne metaforyzacje są żywe także współcześnie; przykładem oskarżenia padające w debatach politycznych, że przeciwnik cierpi na mentalny AIDS. Por. S. Sontag, AIDS and Its Metaphors, dz. cyt., s. 154. W ostatnich latach w Polsce osoby LGBTQ są nazywane zarazą przez niektórych prawicowych polityków (a także księży i biskupów).

48 Była nazywana Babilonem (z racji przepychu i rozwiązłości). Por. P. Muratow, dz. cyt., s. 37. Byron z kolei nazwał ją Sodomą („sea Sodom”). Por. T. Turner, dz. cyt., s. 5, 66). Wenecja przyciągała ludzi o niejednoznacznej seksualności, co potwierdza nowela Gustawa Herlinga-Grudzińskiego Biata noc mitości. Stary reżyser teatralny przybył na lagunę ze swoją przyrodnią siostrą, z którą pozostawał od młodości w kazirodczym związku; celem podróży była operacja oczu, mająca przywrócić mu wzrok. W Wenecji jego siostra odkryła, że „miłosne fluidy wiszą tu w powietrzu, jak latem zgniłe i trujące wyziewy laguny, opisane w noweli Manna”. G. Herling-Grudziński, Biała noc mitości. Opowieść teatralna [w:] tegoż, Dzieła zebrane, t. 6: Opowiadania wszystkie, vol. 2, Kraków 2017, s. 410. W innym utworze (Portret wenecki) Herling-Grudziński opisał matkę, która po śmierci syna położyła się na jego zwłokach „jakby był jej kochankiem, a nie synem". Tenże, Portret wenecki [w:] tegoż, Dzieta zebrane, t. 6, vol. 2, dz. cyt., s. 30.

49 Por. G. Härle, Männerweiblichkeit: Zur Homosexualität bei Klaus und Thomas Mann, Athenäum, Frankfurt am Main 1988, cyt. za: E. Shookman, Thomas Mann's „Death in Venice”: A Novella and Its Critics, dz. cyt., s. 198.

50 M.V. Llosa, dz. cyt., s. 23.

51 Por. K. Hiller, Wo bleibt der homoerotische Roman?, „Jahrbuch für sexuelle Zwischenstufen” 1914, nr 14 (3), s. 338; cyt. za: E. Shookman, Thomas Mann's „Death in Venice”: A Novella 
Aschenbach skrywa swe uczucia, zachowując przestrzenny i towarzyski dystansu wobec Tadzia i jego rodziny, tak władze miasta ukrywają rzeczywiste rozmiary zarazy w uspokajających komunikatach.

Odczytanie epidemii jako obrazu upadku człowieka wpisuje się w znaną od wieków metaforyzację chorób, które uważano za zewnętrzne ekspresje ukrytych stanów duszy ${ }^{52}$. Choroba nie jest zatem rzeczywistością autonomiczną, lecz znakiem podświadomych pragnien i lęków, które w inny sposób nie mogą się ujawnić. Model taki akceptował chociażby Immanuel Kant, źródła chorób (zwłaszcza psychicznych) upatrując w emocjach zakłócających działanie rozumu i woli ${ }^{53}$. Motyw ten obecny jest także w listach Franza Kafki, który skłonny był uznawać własną chorobę nie tylko za fizyczny stan organizmu, lecz także za oznakę nieudanego życia ${ }^{54}$. Podobnie swoje kłopoty zdrowotne postrzegał Aschenbach, widząc w nich przejaw wewnętrznego rozkładu, któremu uległ pod wpływem miłości do Tadzia; sama zatem podatność na chorobę jest skutkiem osłabienia artystycznej i moralnej dyscypliny. Nowela staje się w ten sposób zapisem archaicznej mentalności, zgodnie z którą choroba i śmierć są oznaką winy, Aschenbach umarł wszak z powodu występnej miłości do dziec$\mathrm{ka}^{55}$. Nie chodzi jednak o karę zesłaną przez Boga, lecz o skutek działań bohatera, który pozostał w zakażonym mieście, aby oglądać Tadzia (i z tego powodu ukrył przed matką chłopca prawdę o szalejącej epidemii):

and Its Critics, dz. cyt., s. 25. W noweli Manna widać wyraźny związek między Wenecją jako symbolem moralnego rozkładu a grzeszną miłością Aschenbacha. Por. M. Bordry, dz. cyt.

52 Por. S. Sontag, Illness as Metaphor, dz. cyt., s. 44.

53 Por. I. Kant, Antropologia w ujęciu pragmatycznym, tłum. E. Drzazgowska, P. Sosnowska, Warszawa 2005, s. 119-140.

54 „Ja (...) w skrytości serca nie uważam tej choroby bynajmniej za gruźlicę, a w każdym razie nie za gruźlicę przede wszystkim, lecz za moje ogólne bankructwo. Wierzyłem, że jakoś to jeszcze będzie, ale nie wyszło. - Krew nie pochodzi z płuca, lecz od ciosu, czy raczej od decydującego ciosu, zadanego przez jednego z walczących”. F. Kafka, Listy do Felicji i inne z lat 1912-1916, tłum. I. Krońska, Warszawa 1976, t. 2, s. 353. Tymi walczącymi były dwie siły: Dobro i Zło. Por. tamże, s. 352. Podobne interpretacje znajdują się w listach Kafki do Maxa Broda, w których rana w płucach jest jedynie symbolem głębszej rany duchowej, związanej z nieszczęśliwą miłością do Felicji. Por. F. Kafka, Listy do rodziny, przyjaciót wydawców, wyb. P. Urbański, A. Urbańska, tłum. R. Urbański, Warszawa 2010, s. 161. Tej oceny Kafka nie zmienił też później, ironizując o chorobie płuc jako chorobie umysłu. „Było tak, że mózg nie mógł już znieść nałożonych mu trosk i boleści. Oświadczył: „Ustępuję; jeżeli tu jednak jest jeszcze ktoś, komu choć trochę zależy na utrzymaniu całości, to niech ujmie mi trochę ciężaru i będzie to jeszcze szło«. Wtedy zgłosiło się płuco, nie miało chyba wiele do stracenia. Pertraktacje między mózgiem a płucem, które toczyły się poza moją świadomością, musiały być straszliwe". F. Kafka, Listy do Mileny, tłum. F. Konopka, Kraków 1959, s. 17. Kafka uznaje chorobę za swoisty projekt egzystencjalny a nawet wybór swego losu. Por. M. Hakselman, Mikrokosmos rany. Granica u Kafki, „Teksty Drugie” 2013, nr 6, s. 261.

55 Por. S. Sontag, Illness as Metaphor, dz. cyt., s. 37. 
- Trzeba milczeć! - szeptał gwałtownie i: - Będę milczał! - Świadomość jego współwiedzy, jego współwiny, oszałamiała go, jak małe ilości wina oszałamiają znużony mózg. Obraz nawiedzonego plagą i opuszczonego miasta, unoszący się mętnie przed oczyma jego duszy, rozpalił w nim nadzieje nieuchwytne, przekraczające granice rozumu, nadzieje o przeogromnej słodyczy. Czym było jego tkliwe szczęście, o którym przedtem marzył chwilę, w porównaniu z tymi oczekiwaniami? Cóż warta dlań była jeszcze sztuka i cnota wobec korzyści chaosu? Milczał i został (s. 182).

Symbolikę epidemii można rozszerzyć, upatrując w niej nie tylko upadku Aschenbacha, lecz także obrazu kryzysu kultury zachodniej, a nawet - grzeszności ludzkiej natury; sugerowałoby to, że śmiercionośna zaraza oznacza zło tkwiące w człowieku, które przybiera niekiedy rozmiary demoniczne. Indyjska cholera zatem, z pozoru będąc jedynie scenerią wydarzeń, czyni z Wenecji Manna wyjątkowo mroczny świat ${ }^{56}$.

\section{4. „Europa drżała, że upiór może wtargnąç”}

Skoro Aschenbach jest reprezentantem kultury europejskiej, to jego upadek należy usytuować na szerszym tle duchowego kryzysu Zachodu ${ }^{57}$. Potwierdzeniem jest epidemia, która burzy społeczny i moralny ład; w sytuacji powszechnego zagrożenia tracą bowiem ważność dotychczasowe reguły i wzorce kulturowe. Można zatem powiedzieć, że:

inicjacja Aschenbacha przebiega na dwóch poziomach: ciała i ducha, zmierzając do podważenia odrębności obu pierwiastków. Ich radykalne przeciwstawienie i wiara, że duch może i powinien opanować cielesność, są błędem pisarza i całej kultury, którą reprezentuje ${ }^{58}$.

Indyjska cholera okazuje się nie tylko stanem duszy Aschenbacha, lecz także chorobą Europy, przy czym zagrożenie ma wymiar zarówno wewnętrzny, jak i zewnętrzny.

Zagrożenie wewnętrzne to negatywne tendencje kultury zachodniej, zmierzającej ku samozagładzie ${ }^{59}$. W noweli zauważalna jest obecność nihilizmu

56 Por. M.V. Llosa, dz. cyt., s.19.

57 „Zbyt zajęty zadaniami, które wkładało nań jego »ja« i europejska dusza (die europäische Seele), zbyt obarczony zobowiązaniami tworzenia, nie bardzo chętny rozrywkom, aby być miłośnikiem wielobarwnego świata zewnętrznego, zadowalał się zupełnie pojęciem o świecie, jakie zdobyć może każdy człowiek na ziemi, nie ruszając się daleko ze swego kąta; nigdy też nie zaznał pokusy opuszczenia Europy" (s. 139, wyd. niemieckie s. 193).

58 M. Wołk, dz. cyt., s. 51.

59 Por. M.V. Llosa, dz. cyt., s. 23. 
jako niszczycielskiej siły, która wkrótce doprowadzi do wybuchu wojny światowej ${ }^{60}$. Aschenbach bowiem, chociaż był pisarzem dbającym przede wszystkim o czystość formy, to jednak sławę zyskał głównie dzięki temu, że potrafił wyrazić doświadczenia i rozterki swego pokolenia (s. 144). Czarując młodych „swym cynizmem w stosunku do wątpliwej istoty sztuki, samego artyzmu" (s. 143) ${ }^{61}$, bohater Manna może zostać uznany za typowego dekadenta z początków XX wieku. Odczuwany przez niego pociąg do destrukcji i śmierci uchodził w oczach Manna za stałą tendencję kultury europejskiej, zwłaszcza w epoce romantyzmu. W postaci Aschenbacha widać rezultaty tego procesu, odrzuca bowiem ideały Oświecenia; wprawdzie z pozoru im hołdował, to jednak u kresu życia porzucił mit ładu i rozumu, ulegając gorączce namiętności. Podobną ewolucję przeszedł Hans Castorp; odczuwając romantyczny pociąg do destrukcji i śmierci, zakończył swoją edukację (a zapewne i życie) w okopach. Los obu bohaterów wskazuje zatem na ukryte pragnienie powrotu do barbarzyństwa; Castorp udaje się na wojnę, Aschenbach zaś marzy o wyjeździe do egzotycznej i dzikiej krainy, chcąc zrzucić jarzmo intelektualnego i moralnego rygoryzmu (s. 140). Plany te przypominają rojenia sztubaka, który chce przeżyć fascynującą przygodę, nie krępowany żadnymi zakazami; pisarz znalazł ją w miłości do nastoletniego chłopca.

Równie niebezpieczne są zagrożenia zewnętrzne, których symbolem jest indyjska cholera; przed epidemią drży cała Europa (s. 180), choroba oznacza bowiem inwazję dzikiego i niecywilizowanego Wschodu ${ }^{62}$. Dla ludzi Zachodu bowiem, lękających się tego, co obce, Europa oznacza nie tylko kolebkę kultury, lecz także centrum świata; z takiej pozycji zaś wszelka inność jawi się jako zagrożenie. W tym kontekście szczególnego znaczenia nabiera fakt, że indyjska cholera dotarła do Wenecji; to miasto bowiem, zbudowane na przekór żywiołom przyrody, wydaje się kwintesencją kultury, polegającej na okiełznaniu natury. Wenecja świadczy zatem, że europejski duch potrafi wprowadzić

60 G. Lukács interpretował nowelę Manna jako obraz barbarzyńskich tendencji, obecnych w cywilizacji niemieckiej. Por. T. Mann, Jak powstat Doktor Faustus, dz. cyt., s. 116. Mann taką wykładnię aprobował, uważając, że udało mu się wskazać na te siły, które doprowadziły do obu wojen światowych. Por. H. Lehnert, Tomasza Manna wtasne interpretacje „Śmierci w Wenecji”, tłum. A. Rogalski [w:] Tomasz Mann w oczach krytyki światowej, dz. cyt., s. 89. Mimo to wątpliwa jest teza, że dałoby się uniknąć pierwszej wojny światowej, gdyby Europa w porę dostrzegła groźbę estetyzmu i dekadentyzmu opisaną w noweli. Por. K.D. Vogt, Vision and Revision: The Concept of Inspiration in Thomas Mann's Fiction, New York 1987, s. 54; cyt. za: E. Shookman, Thomas Mann's „Death in Venice”: A Novella and Its Critics, dz. cyt., s. 139.

${ }^{61},(\ldots)$ ja, während seine Bildwerke die gläubig Genießenden unterhielten, erhoben, belebten, hatte er, der jugendliche Künstler, die Zwanzigjährigen durch seine Zynismen über das fragwürdige Wesen der Kunst, des Künstlertums selbst in Atem gehalten” (s. 199).

${ }_{62}$ Groźba Wschodu jest obecna w rozmaitych dyskursach zachodnich, także chrześcijańskich; przykładem jest nazwanie manicheizmu „zarazą ze Wschodu”. Por. H. Daniel-Rops, Kościót wczesnego średniowiecza, tłum. zbiorowe, Warszawa 1969, s. 35, przypis 22. 
ład w miejsce chaosu ${ }^{63}$. W przeciwieństwie do niego Azja okazuje się krainą dzikości, której symbolem jest - siejąca spustoszenie - zaraza.

Mit Europy jako wcielenia rozumu i Azji jako synonimu dzikości pojawia się w monologu urzędnika brytyjskiego biura podróży (s. 180-181). Fakt zatem, że europejska dusza Aschenbacha uległa wschodniej chorobie, może zapowiadać triumf barbarzyństwa i upadku cywilizacji ${ }^{64}$. Pierwszą ofiarą inwazji jest Wenecja, od wieków funkcjonująca na granicy dwu kręgów kulturowych. Z jednej strony stąd właśnie ruszały średniowieczne krucjaty, uważane przez ich uczestników za narzędzie cywilizowania świata; z drugiej strony - okazuje się bramą, przez którą mogą wtargnąć do Europy różne epidemie. Indyjska cholera może więc zostać uznana za symbol bezradności Zachodu wobec zewnętrznych zagrożeń; racjonalistyczna i antyreligijna Europa przegrywa walkę „z irracjonalnym, ekstatycznym, religijnym witalizmem bardziej archaicznego Wschodu czy Południa" ${ }^{65}$. Proces rozkładu już trwa ${ }^{66}$, o czym świadczy nieskuteczność władz Wenecji w walce z zarazą.

\section{5. „Wylęgła z ciepłych bagien gangesowej delty, zaraza szalała w całym Hindustanie"}

Nietrudno dostrzec, że epidemia jako symbol kryzysu europejskiej kultury, będącego następstwem jej konfrontacji z Azją, wyraża mentalność kolonialną, wraz z charakterystycznym dla niej poczuciem wyższości Zachodu wobec reszty świata. Dyskurs ten jest widoczny w opisie źródeł zarazy, przedstawionym przez urzędnika brytyjskiego biura podróży (s. 180-181). Azjatyckie pochodzenie epidemii wskazuje bowiem na zagrożenia płynące ze Wschodu, jednocześnie potwierdzając cywilizacyjną wyższość Europy. Indyjska cholera jest zatem nie tylko chorobą, lecz także formą usprawiedliwienia europejskiej dominacji; Zachód dysponuje wszak wysoko rozwiniętą medycyną, którą należy upowszechnić w świecie ${ }^{67}$. Azja z kolei jest pozbawiona skutecznej ochrony sanitarnej, wobec czego nie radzi sobie z epidemią, stanowiąc zagrożenie dla Europy ${ }^{68}$. Według Europejczyków bowiem, ludzie Wschodu żyją

63 Por. A. Ghosh, dz. cyt., s. 5.

64 Por. M.V. Llosa, dz. cyt., s. 23. Odbywającego karę Raskolnikowa męczy sen o zarazie, która dotarła z Azji do Europy. Bakteriami były duchy obdarzone rozumem i wolą; zakażeni nimi ludzie uważali, że są wybrańcami, znającymi prawdę, wobec czego mordują siebie wzajemnie w niepohamowanej złości. Por. F. Dostojewski, Zbrodnia i kara, tłum. C. Jastrzębiec-Kozłowski, Warszawa 2019, s. 634-635.

65 Por. M. Wołk, dz. cyt., s. 36.

66 Por. M.V. Llosa, dz. cyt., s. 23.

67 Por. A. Ghosh, dz. cyt., s. 6.

68 W XIX wieku cholerę powszechnie uważano za skutek braku odpowiednich zabezpieczeń sanitarnych. Por. S. Sontag, AIDS and Its Metaphors, dz. cyt., s. 143. 
w złych warunkach sanitarnych i nie przestrzegają zasad higieny, co jest przyczyną zakażeń. Wprawdzie nie są winni, że urodzili się w niezdrowym klimacie, nie mają jednak skutecznych środków medycznych pozwalających ograniczyć rozprzestrzenianie się chorób zakaźnych; z tego powodu obowiązkiem Europy jest cywilizowanie Azji ${ }^{69}$. Medycyna staje się w ten sposób istotnym elementem kulturowego podboju ${ }^{70}$; wprawdzie Europejczycy widzą w niej skuteczne remedium na choroby przywożone z innych rejonów świata, to jednak nie ma również wątpliwości, że wraz z eksportem medycyny Zachód niósł tubylcom własne idee, niszcząc (a przynajmniej kwestionując) ich kultury ${ }^{71}$.

Kolonialny wydźwięk ma też sposób, w jaki nowela ukazuje źródła epidemii. Chociaż jest prawdą, że cholera rozpoczęła się w delcie Gangesu, wobec czego można ją nazwać indyjską, jednak teza ta w ustach Anglika znaczy, że choroba nie pochodzi z Europy. Skoro zaś została przywleczona z obcej i dzikiej krainy, to Europejczycy nie tylko nie odpowiadają za jej rozprzestrzenianie się, lecz także są jej niewinnymi ofiarami ${ }^{72}$. Kontrast między Europą i Azją jest zatem podwójny: $\mathrm{z}$ jednej strony mamy przestrzegających zasad higieny Europejczyków oraz żyjących w brudzie Azjatów, z drugiej - Europa, z racji swego umiarkowanego klimatu, nie jest źródłem zakażeń pochodzących z tropikalnej Azji ${ }^{73}$. W świetle takiego opisu winnymi epidemii stają się mieszkańcy doliny Gangesu, gdzie pojawiło się pierwsze ognisko zakażenia (s. 180). Ważne jest jednak to, że diagnozę stawia przedstawiciel kraju, pod którego panowaniem znajdowały się wówczas Indie. Wprawdzie angielscy koloniści mogli postrzegać azjatycki klimat jako uciążliwy i groźny, upatrując w nim źródła swych chorób, to jednak urzędnikowi biura podróży nie przychodzi do głowy, że również Anglia mogła się przyczynić do przewiezienia cholery z Indii do Europy. Za obecność epidemii w Wenecji trudno wszak winić Hindusów, zwłaszcza że narrator nie odnotował żadnego z nich na lagunie; można zresztą wątpić, czy mieszkańców doliny Gangesu było stać na takie turystyczne eskapady ${ }^{74}$. Nawet jednak, jeśli cholerę sprowadzili kolonizatorzy, to i tak obwiniają za nią Azjatów.

69 Por. A. Ghosh, dz. cyt., s. 3.

70 Por. tamże, s. 10 .

71 Por. tamże, s. 7.

72 Idea zewnętrznego pochodzenia epidemii jest znana od wieków, źródła zarazy bowiem zwykle lokalizowano w innych krajach, co odzwierciedlały także nazwy: w Anglii mówiono o chorobie francuskiej, we Francji - o chorobie niemieckiej itp. Por. S. Sontag, AIDS and Its Metaphors, dz. cyt., s. 135-136. W wypadku AIDS powstała nawet (rozpowszechniana przez KGB) hipoteza, jakoby wirus HIV wyprodukowano w laboratoriach CIA i przetransponowano do Afryki jako broń biologiczną; miał on wrócić do USA za pośrednictwem homoseksualnych misjonarzy. Por. tamże, s. 140. Niezależnie od kontekstu politycznego AIDS w każdym rejonie świata uchodzi za trojańskiego konia pochodzącego z zewnątrz. Por. tamże, s. 168.

73 Por. A. Ghosh, dz. cyt., s. 1, 8.

74 W dyskursie kolonialnym nawet $\mathrm{z}$ biedy można podbitym ludom czynić zarzut, ale to temat osobny. 
Nowela Manna wskazuje na jeszcze inny wymiar uprzedzeń kolonialnych, związany z lękiem zdobywców przed ludami podbitymi. Skoro bowiem Aschenbach umarł w Wenecji, która - z racji swego położenia - miała ożywione kontakty ze Wschodem, to jego śmierć można uznać za skutek zetknięcia się z obcym światem ${ }^{75}$. Nawet bowiem, jeśli pisarz marzył o egzotyce, to nie planował wyjazdu aż do tygrysów (s. 140); mimo to na lagunie zetknął się z indyjską cholerą, co doprowadziło go do śmierci. Lepiej uczynili zatem ci, którzy wyjechali z Wenecji, unikając wschodniego zagrożenia. Sam Aschenbach zresztą nigdy nie odczuwał potrzeby opuszczania Europy (s. 139), nie tęsknił do poznawania innych kultur. Wprawdzie zetknięcie z obcymi pojęciami nie musi prowadzić do ich przejęcia (a tym bardziej do zatrucia własnej duszy), może jednak skłaniać do zastanowienia nad słusznością własnych. Taka była też pierwsza reakcja pisarza, który - zakochawszy się w Tadziu - porzucił dotychczasowy styl życia; ostatecznie zetknięcie z innym światem okazało się dla jego europejskiej duszy zgubne.

Nawet uznając interpretację kolonialną noweli za słuszną, należy zauważyć, że wpisuje się ona w nowoczesny obraz świata, zgodnie z którym źródeł epidemii należy upatrywać raczej w klimacie i niedostatkach sanitarnych niż w podstępnych działaniach wroga. $Z$ tego powodu w Wenecji nie obserwujemy zachowań polegających na poszukiwaniu kozła ofiarnego; w średniowieczu bowiem i wczesnej nowożytności wybuch zarazy skutkował poszukiwaniem winnych, prowadząc do pogromów ${ }^{76}$. W noweli Manna znajdujemy wprawdzie tezę o różnicy między rozwiniętą cywilizacyjnie Europą a prymitywną Azją, to jednak nie prowadzi ona do prześladowań. Powodem nie jest fakt, że dolina Gangesu leży zbyt daleko, ani to, że na lagunie trudno spotkać Hindusów, lecz uznanie epidemii za zjawisko przyrodnicze. Interpretacja ta nie wydaje się jednak zupełnie wolna od kulturowych uprzedzeń, okazuje się bowiem, że za źródło cholery uważa się powszechnie zarówno klimat doliny Gangesu, jak i brak higieny ${ }^{77}$. Sugeruje to, że choroba jest nie tylko zjawiskiem naturalnym, na które człowiek nie ma wpływu, lecz także skutkiem braku medycyny i nawyków sanitarnych. Potwierdza to los Aschenbacha; jeśli bowiem rzeczywiście zaraził się cholerą, jedząc przejrzałe i nieumyte poziomki, to powodem zakażenia była jego własna nieostrożność. Łatwo stąd o wniosek, że główną przyczyną rozwoju epidemii są ryzykowne działania ludzi; jeśli zatem Aschenbach nie zjadłby nieumytych poziomek lub wyjechał z Wenecji, to uniknąłby śmierci. Idąc tym tropem dalej, można przekonywać, że jeśliby dolina Gangesu była

75 Por. tamże, s. $1,8$.

76 „Podczas epidemii dżumy funkcjonowały wszystkie stereotypowe oskarżenia w stosunku do Żydów oraz innych kolektywnych kozłów ofiarnych”. R. Girard, Koziot ofiarny, tłum. M. Goszczyńska, Łódź 1987, s. 27.

77 Por. A. Ghosh, dz. cyt., s. 7. 
objęta ochroną medyczną, to cholery w ogóle by nie było (a przynajmniej nie dotarłaby aż do Wenecji).

Kolonialna interpretacja epidemii dopełnia w ten sposób jej symbolikę ontologiczną, zgodnie z którą jest ona obrazem śmiertelności człowieka. W zglobalizowanym świecie bowiem, dowolna choroba zakaźna - niezależnie od miejsca powstania - zagraża wszystkim. Podobnie było w wypadku indyjskiej cholery, opisanej przez Manna, która „wędruje” po świecie, obejmując coraz to nowe obszary (s. 180). Zrodzona w dolinie Gangesu szalała w całych Indiach, skąd kupcy syryjscy przywieźli ją do portów śródziemnomorskich; jednocześnie dotarła do Chin, Persji i Afganistanu, a nawet do Astrachania i Moskwy (s. 180). Głównym narzędziem ekspansji był handel ${ }^{78}$; wprawdzie kontakty kupieckie stwarzają okazję do nawiązania twórczych relacji kulturowych z innymi narodami, to jednak są również zagrożeniem, przenosząc choroby ${ }^{79}$. Zjawisko to ma także drugie oblicze, kontakty z ludźmi innych kultur mogą bowiem prowadzić do wrogości i wojen, zakaźna choroba zaś może wytworzyć ogólnoludzką solidarność wobec wspólnego zagrożenia. Jeśli zatem mentalność kolonialna skłania do poszukiwania winnych wybuchu epidemii, to globalizm wskazuje na konieczność niesienia sobie wzajemnej pomocy.

Złożoność symboliki cholery w noweli Manna nie powinna dziwić, ponieważ bliskość i masowość śmierci, charakterystyczna dla epidemii, rodzi nie tylko lęk przed nią, lecz także rozmaite próby jej zrozumienia i oswojenia. Przede wszystkim jednak ludzie usiłują stawić czoła zagrożeniu, zajmując wobec niej określony postawy.

78 Por. tamże, s. 6.

79 Wskazał na to Ignacy Rzecki. „Rok 1879 dopiero się zaczął, ale niechaj go kaczki zdepczą!... Anglicy, jeszcze nie wygrzebawszy się z Afganistanu, już mają wojnę w Afryce, gdzieś na Przylądku Dobrej Nadziei, z jakimiś Zulusami. Tu zaś, w Europie, ani mniej, ani więcej, tylko wybuchła dżuma w okolicach Astrachania i lada dzień może do nas zajrzeć.

Co my mamy przez tę dżumę!... Kogo spotkam, mówi: „Co, dobrze wam sprowadzać perkaliki z Moskwy? Zobaczysz pan, że razem z nimi sprowadzicie morową zarazęu. A ile się to odbiera anonimów wymyślających na czym świat stoi! Zdaje mi się jednak, że autorami ich są przede wszystkim kupcy, nasi współzawodnicy, albo też fabrykanci perkalików łódzkich.

Ci utopiliby nas w łyżce wody, choćby żadnej dżumy nie było”. B. Prus, Lalka, Warszawa 1966, t. 2, s. 193-194. 


\section{Postawy wobec epidemii}

Epidemia zmusza do podjęcia działań mających jej przeciwdziałać. Najważniejsze okazuje się zarządzanie zarazą, będące obowiązkiem władzy; Mann podejmuje ten wątek z charakterystyczną dla siebie ironią, a nawet krytycyzmem wobec urzędników Wenecji (1). Nowela ukazuje również egoizm ludzi zmagających się ze wspólnym zagrożeniem (2) oraz akty bezprawia (3).

\section{1. „Stan zdrowotny nigdy nie był lepszy”}

Władze Wenecji od początku ukrywały epidemię, nie informując o jej wybuchu ani rozmiarach; już w połowie maja zmarły dwie osoby, co zatajono (s. 180). Przemilczanie i zaprzeczanie były odtąd stałą strategią władzy, mimo iż liczba ofiar rosła, a baraki izolacyjne dla chorych zapełniły się już na początku czerwca (s. 181); wśród ludności krążyły pogłoski o kilkudziesięciu zmarłych w każdej dzielnicy (s. 180). Grozę potęgował fakt, że wyzdrowienia były rzadkie $(80 \%$ zakażonych umierało), sama choroba zaś przebiegała gwałtownie (s. 180); mimo to władze ograniczyły się do przestróg przed wodą z kanałów i owocami morza. „Na rogach ulic widniały drukowane obwieszczenia, które z powodu pewnych schorzeń systemu gastrycznego, będących przy tej pogodzie na porządku dziennym, po ojcowsku ostrzegały ludność przed spożywaniem ostryg i muszli, jako też przed wodą z kanałów" (s. 172) ${ }^{80}$. Wprawdzie treść ostrzeżeń brzmiała poważnie, to jednak ton był uspokajający, sugerował, że chodzi raczej o zalecenia przesadnie ostrożnej policji niż o realne zagrożenie. Podobnie gazety informowały o groźbie zarazy, jednocześnie negując jej istnienie:

Twierdzenia i zaprzeczenia luzowały się w nich nawzajem. Liczba zachorzeń i wypadków śmiertelnych miała wynosić dwadzieścia, czterdzieści, ba, sto i więcej i wnet potem każde wystąpienie zarazy, jeśli nie spotkało się z natychmiastowym zaprzeczeniem, ograniczano do zupełnie odosobnionych, z zewnątrz zawleczonych wypadków. Ostrzegawcze uwagi, protesty przeciw niebezpiecznej grze włoskich władz były rozsiane, pewności nie można było uzyskać (s. 175).

Ponieważ zaś władze miasta twierdziły, że „stan zdrowotny nigdy nie był lepszy" (s. 180), jedyne wiarygodne informacje można było znaleźć w gazetach niemieckich (s. 172). Właśnie z nich Aschenbach dowiedział się o Austriaku, który zmarł w domu po kilku dniach spędzonych w Wenecji (s. 180);

80 Takie były typowe ostrzeżenia władz w każdej epidemii cholery. Por. M. Ostaszewski, dz. cyt., s. 125 . 
inni ludzie takich informacji znać nie mogli (s. 172). Z czasem jednak również to źródło przestało być dostępne, ponieważ z hotelu zniknęły gazety niemieckie (s. 175).

Pomimo jej negowania cholera zbierała śmiertelne żniwo (s. 180). Polityka władz nie rozmijała się jednak całkowicie z oczekiwaniami społecznymi, wielu ludzi bowiem wolało nie znać prawdy ${ }^{81}$. Brak informacji pozwalał zachować nadzieję, że sytuacja jest pod kontrolą; przemilczenia i kłamstwa odpowiadały ludzkiej potrzebie iluzji. Władza stała się w ten sposób jedynym dysponentem prawdy, a zarazem ośrodkiem jej reglamentacji, dzięki czemu mogła konstruować rzeczywistość odpowiadającą własnym interesom.

$\mathrm{Z}$ pewnością kłamstwa można niekiedy usprawiedliwić; władza powinna bowiem ukryć niektóre fakty w sytuacji, gdyby ich ujawnienie groziło katastrofą, wywołaną chociażby paniką. Jeśliby zatem istniały uzasadnione przesłanki, że ujawnienie pełnej prawdy o epidemii wywoła zamieszki, które przyniosą większą liczbę ofiar niż sama epidemia, to kłamstwo byłoby usprawiedliwione. W wypadku zarazy opisanej przez Manna taka sytuacja nie zachodzi, ponieważ motywacje władz Wenecji były wyłącznie ekonomiczne. Zdawał sobie z tego także sprawę Aschenbach, wiedząc, że włodarze miasta kłamią z żądzy zysku (s. 174). Opinię tę potwierdza narrator noweli:

obawa przed ogólnymi szkodami, wzgląd na niedawno otwartą wystawę obrazów w ogrodach publicznych, na ogromne starty, które w razie paniki i zdyskredytowania groziły hotelom, sklepom, całemu różnorakiemu przemysłowi turystycznemu, okazały się w mieście potężniejsze niż miłość prawdy i szacunek dla międzynarodowych umów (s. 181).

Wyjątkiem była postawa kierownika urzędu sanitarnego Wenecji, który ustąpił ze stanowiska, aby nie uczestniczyć w zbiorowym kłamstwie. Sprzeciw ten okazał się jednak gestem czysto symbolicznym, ponieważ miejsce zdymisjowanego urzędnika zajął człowiek bardziej ugodowy, dzięki czemu kłamstwo szerzyło się dalej (s. 181).

Podstawowym celem urzędników było utrzymanie władzy; nie chodziło zatem o ratowanie zakażonego miasta, lecz o zachowanie własnych wpływów. Polityka okazała się zarządzaniem epidemią, które ma przynieść korzyść rządzącym. Skoro zaś zaraza jest na tyle groźna, że nie sposób uniknąć wielu ofiar, to uznanie jej istnienia jest dla władzy niekorzystne, okazałaby się bowiem niezdolna do ochrony obywateli. $Z$ punktu widzenia rządzących informacje o zagrożeniu można ujawnić tylko wtedy, gdy nie jest ono duże, wobec czego można

81 Por. A. Ghosh, dz. cyt., s. 4. W miejscowościach, w których cholera zebrała dużo ofiar, jeszcze po latach samo jej wspomnienie wywołuje grozę. Por. M. Ostaszewski, dz. cyt., s. 121-123. W niektórych kulturach istniało tabu cholery, zakazujące jej wspominania, ponieważ mogłoby ją znowu wywołać. Por. tamże, s. 124. 
je opanować; wówczas nawet przesadne nagłośnienie kryzysu leży w interesie władzy, dowodzi bowiem jej skuteczności w działaniu. Ponieważ jednak urzędnicy weneccy nie radzą sobie z epidemią - zaprzeczają jej istnieniu. Zaraza staje się w ten sposób nie tyle problemem medycznym, ile politycznym.

W milczącej zmowie z władzami są też mieszkańcy miasta, którzy - wiedząc o epidemii - konsekwentnie jej zaprzeczają (s. 181). Przykładem jest fryzjer, który namawia Aschenbacha do pozostania w mieście, choroby bowiem nie trzeba się bać (s. 171). Paradoksalnie jednak, właśnie dzięki tym słowom pisarz dowiedział się o zarazie, fryzjer uspokajał go bowiem tylko dlatego, że nie przypuszczał, iż Aschenbach o niczym nie wie; pytanie jednak, o jaką chorobę chodzi, zbył milczeniem: „udał zajętego, puścił pytanie mimo uszu. Zapytany natarczywiej oświadczył, że o niczym nie wie, i z zakłopotaną swadą starał się zmienić temat" (s. 171). Podobnie zachowują się inni rozmówcy pisarza sklepikarz (s. 172), kierownik hotelu czy muzykant (s. 175); każdy przekonuje, że dezynfekcja ma charakter zapobiegawczy, wynikający z nadmiernej ostrożności policji (s. 175, 178). Podobnej odpowiedzi udzielił Aschenbachowi na początku rozmowy urzędnik brytyjskiego biura podróży; prawdę wyjawił dopiero wtedy, gdy zawstydził się, że powtarza oficjalne kłamstwa (s. 179-181).

Strategia zaprzeczania nie jest skuteczna, ponieważ brak informacji rodzi plotki na temat rozmiarów epidemii i planowanej kwarantanny. Demaskacja kłamstw następuje też zupełnie przypadkowo (o czym świadczą słowa fryzjera) lub pokątnie (co potwierdza zawstydzony Anglik, radzący Aschenbachowi jak najszybszy wyjazd z Wenecji) (s. 181). O niebezpieczeństwie świadczą też dezynfekcja miasta (s. 172), wzmożony ruch gondoli na wyspę cmentarną (s. 181) oraz masowa ucieczka turystów (s. 183), zwłaszcza niemieckojęzycznych (s. 171). „Prawda, widać, wyszła na jaw, paniki mimo silnej solidarności zainteresowanych nie dało się stłumić dłużej” (s. 183). Wynika z tego, że kłamstwo i przemilczenie nie muszą być skuteczną strategią powstrzymania paniki, również bowiem niesprawdzone pogłoski mogą spowodować nieprzewidziane i niepożądane zachowania. Wyjazdy turystów ukazują również inny aspekt problemu, związany nie tylko z egoizmem władz czy mieszkańców Wenecji, lękających się o dochody, lecz także z brakiem solidarności między osobami narażonymi na zakażenie, turyści bowiem nie przekazują sobie informacji o panującej zarazie.

\section{2. „Z biegiem sezonu frekwencja jego hotelu malała”}

Albert Camus przekonywał, że kara śmierci jest zerwaniem elementarnej solidarności między ludźmi ${ }^{82}$. Jej główne zło nie polega na możliwości pomyłki sądowej, braku proporcji między winą a karą, braku szansy dla zbrodniarza na

82 Por. A. Camus, Rozważania o gilotynie, tłum. W. Szydłowska [w:] W. Szydłowska, Camus, Warszawa 2002, s. 165-204. 
poprawę czy zabijaniu w imię prawa, lecz na wykluczeniu skazanego z ludzkiej wspólnoty - przestaliśmy go bowiem uważać za jednego z nas. Zabijamy w imię absolutnej sprawiedliwości, uważając się za bogów, mających prawo decydować o życiu i śmierci innych. Absurd tej sytuacji polega na tym, że wszyscy jesteśmy śmiertelni; mimo to z naszego wspólnego losu czynimy karę, zachowując się tak, jakbyśmy sami byli nieśmiertelni.

Podobnym zerwaniem więzi z innymi ludźmi jest wojna, kiedy mordujemy wrogów, jednocześnie za wszelką cenę ratując siebie i bliskich. Również klęska głodu może spowodować, że innych głodujących nie będziemy uznawać za braci w niedoli, lecz za rywali w dostępie do jedzenia; wszak w sytuacji skrajnego wyczerpania ludzie gotowi są wzajemnie siebie zabijać ${ }^{83}$. Podobnie dzieje się podczas epidemii śmiertelnej choroby, kiedy zdecydowana większość ludzi chce przeżyć; nietrudno zatem wyobrazić sobie chęć uzyskania pomocy medycznej nawet za cenę niesprawiedliwości (pozbawienia tego prawa innych, bardziej potrzebujących). W obliczu powszechnego zagrożenia możliwa jest zarówno solidarność z innymi, jak i egoizm; trudno zresztą potępiać ludzi za to, że bardziej zależy im na ocaleniu siebie niż na pokonaniu epidemii. Zjawisko to opisał także Mann na przykładzie kolejnego kręgu milczenia, jakim otoczona była indyjska cholera na lagunie.

Oprócz kłamstwa władz i mieszkańców Wenecji zaraza jest też przemilczana przez turystów, którzy ukradkiem opuszczają zakażony teren. Goście bowiem, którzy dowiedzieli się o zagrożeniu, nie komunikują swego odkrycia innym, lecz czym prędzej wyjeżdżają, chcąc uniknąć zakażenia i kwarantanny. W interesie tych, którzy poznali prawdę, nie jest wywołanie paniki wśród pozostałych przyjezdnych; gdyby wszyscy wiedzieli, co się dzieje, wielu mogłoby nie mieć szans na rychły wyjazd z laguny. $\mathrm{Z}$ tego powodu najlepszą strategią jest dochowanie sekretu, ostrzeganie innych bowiem byłoby działaniem na własną niekorzyść. Zachowanie to sugeruje, że bardziej typowa jest walka o przetrwanie niż międzyludzka solidarność; w sytuacji zagrożenia myślimy przede wszystkim o sobie i bliskich, nie troszcząc się o obcych.

83 Jeden z bohaterów Kazimierza Brandysa przekonywał, że etyka to tylko kalorie. „W warunkach ścisłej izolacji ograniczenie przydziałów żywnościowych poniżej pewnego minimum stwarza szerokie możliwości oddziaływania. W tych warunkach za cenę dodatkowej racji ludzie wyzwalają się z hamulców moralnych. Działają nowe bodźce. Jeśli na 1000 izolowanych jednostek jest do uzyskania tylko 100 racji dodatkowych, wtedy na każdych dziesięciu ludzi jeden staje się wrogiem dziewięciu pozostałych. Oczywiście można to uważać za regułę dopiero przy zejściu poniżej koniecznego "X « wartości kalorycznych”. K. Brandys, Wywiad z Ballmeyerem [w:] Polska nowela wspótczesna, wyb. T. Bujnicki, J. Kajtoch, Kraków 1975, t. 1, s. 237. Słowa hitlerowskiego zbrodniarza wskazują, że głód może popchnąć człowieka do największych podłości. Nie znaczy to, że są prawdą uniwersalną; przykład ojca Maksymiliana Kolbe świadczy, że człowiek potrafi zdobyć się na heroizm śmierci głodowej, aby ocalić innego. Wymiar ten podkreślał Józef Tischner, upatrując w czynie Kolbego wyjątkowego świadectwa dobra na przekór pesymizmowi filozofów. Por. J. Tischner, Myślenie wedtug wartości, Kraków 2005, s. 7-8. 
W opisanej przez Manna „zmowie” milczenia uczestniczył też Aschenbach. Poznawszy prawdę, miał poczucie wyższości wobec innych ludzi, którzy o zagrożeniu nic nie wiedzieli (s. 181); z urzędnikiem biura podróży zaś łączyło go milczące porozumienie, że sekretu nie zdradzi ${ }^{84}$. Dodatkowym motywem skłaniającym pisarza do zachowania tajemnicy była miłość do Tadzia, Aschenbach bowiem nie chciał wyjeżdżać z Wenecji, aby móc dalej oglądać chłopca; $\mathrm{w}$ jego interesie zatem było to, aby polska rodzina nie dowiedziała się o zarazie. Pisarz obawiał się „tylko tego, że Tadzio mógłby odjechać, i przekonywał się nie bez przerażenia, że nie umiałby już żyć, gdyby to się stało" (s. 172). Marzył nawet o wprowadzeniu kwarantanny, będącej azylem dla jego miłości i stwarzającej szansę przeżycia wyjątkowej przygody (s. 172). Z tego powodu nie poinformował matki Tadzia o epidemii, doskonale wiedząc, że postępuje źle (s. 181-182). Wprawdzie rozważał przez chwilę ujawnienie prawdy, niemniej w planowanym geście widział jedynie akt wzniosłej rezygnacji - na przekór swej miłości do chłopca zgodziłby się na jego wyjazd; w rzeczywistości rozmowę z matką Tadzia chciał odbyć tylko po to, aby móc wreszcie dotknąć chłopca, kładąc mu rękę na głowie (s. 181-182). Ponieważ jednak ostatecznie zrezygnował z poinformowania rodziny Tadzia o zagrożeniu, tajemnica Wenecji stała się też jego tajemnicą (s. 172); pocieszał się jedynie tym, że prawda o epidemii będzie musiała wyjść na jaw, wobec czego dowie się o niej również polska rodzina (s. 183) ${ }^{85}$. To przewrotne alibi moralne Aschenbacha potwierdza, że był rzeczywiście dekadentem, zakochanym nie tylko w pięknym ciele Tadzia, lecz także w rozkładzie, destrukcji i śmierci. Stan epidemii współgra z jego duszą nihilisty, gotowego narazić na śmierć obiekt swej miłości, byle tylko nie stracić go z oczu. Aschenbach rozkoszuje się widokiem Tadzia również dlatego, że widzi jego słabe zdrowie, przypuszczając, że chłopiec nie pożyje długo (s. 159). Ewentualnej śmierci Tadzia nie uważa jednak za powód do rozpaczy; przeciwnie, jako esteta upaja się tym, że piękne ciało chłopca nie uległoby procesom starzenia. Zachwyt nie jest też wolny od zazdrości, gdyby bowiem Tadzio zmarł, to nie mógłby należeć do nikogo innego. Myśli te świadczą, że w duszy Aschenbacha tkwią mroczne instynkty.

84 Można przypuszczać, że urzędnik ten także innych turystów ostrzegał przed zarazą w sposób równie konfidencjonalny.

85 Nie wiadomo, jaką wiedzę o panującej zarazie miała matka Tadzia; pewne jest, że dosyć długo została z dziećmi na lagunie. Powodem mogło być zarówno to, że nic nie wiedziała o epidemii, jak i to, że była zbyt dumna, aby ulec ogólnej panice (s. 183). Możliwe też, że uznała zagrożenie za zbyt małe, aby skracać pobyt. 


\section{3. „Zdarzały się napady rabunkowe, a nawet morderstwa”}

Epidemia to stan kryzysu, który radykalnie zmienia ludzkie życie; z jednej strony rodzi niepewność co do przyszłości, z drugiej - zmusza do zmiany dotychczasowych nawyków i zachowań. Jej bezpośrednim skutkiem jest społeczny chaos ${ }^{86}$, w noweli Manna ukazany jako bezprawie. Społeczne konsekwencje zarazy są zatem równie poważne, jak śmiertelne spustoszenie, które czyni w ludzkim organizmie. Jednym z głównych nieszczęść okazuje się zaburzenie dotychczasowych relacji społecznych, ponieważ w czasie epidemii często rodzi się wrogość wobec innych, traktowanych jako potencjalne źródło zakażenia. Równie poważnym problemem jest ograniczone przestrzeganie prawa i zasad obyczaju, w sytuacji śmiertelnego zagrożenia bowiem ludzie przestają stosować się do wcześniej obowiązujących norm; stan ten może oznaczać powrót do barbarzyństwa.

Historycznym przykładem może być zaraza w Atenach w 430 roku p.n.e., w drugim roku wojny peloponeskiej ${ }^{87}$. Przejmująco opisał ją Tukidydes, wskazując na różne formy przemocy (okradanie i plądrowanie majątków bogaczy) czy rozpustę (każdy chciał maksymalnie wykorzystać pozostały czas, który okazał się dramatycznie krótki):

Zaraza była pierwszym hasłem do szerzenia (...) bezprawia. Dawniej oddawano się użyciu po kryjomu, teraz jawnie korzystano z chwili, widząc, jak szybko umierają bogacze, a ich majątki przejmują biedni. Każdy chciał prędko i przyjemnie użyć życia, uważając zarówno życie jak pieniądze za coś krótkotrwałego. Nikt nie miał ochoty trudzić się dla cnoty; uważał bowiem, że nie wiadomo, czy nie umrze wcześniej, nim ją osiągnie; uchodziło za piękne i pożyteczne to, co było przyjemne i służyło rozkoszy. Ani obawa przed bogami, ani żadne prawa ludzkie nie krępowały nikogo. Jeśli idzie o bogów, ludzie uważali, że pobożność tak samo nie ma żadnego znaczenia, jak i obojętność religijna; widzieli bowiem, że wszyscy na równi giną. $\mathrm{Z}$ pogwałcenia zaś praw ludzkich nikt sobie nic nie robił, bo nikt nie był pewien, czy doczeka wymiaru sprawiedliwości; o wiele cięższy wyrok wisiał nad nim już teraz w postaci zarazy, dlatego każdy chciał przynajmniej użyć życia, zanim go choroba dosięgnie ${ }^{88}$.

Podobnych świadectw dostarcza literatura, chociażby Dekameron Boccaccia, ukazujący rozboje we Florencji w czasie dżumy w roku $1348^{89}$. Epidemia

86 Por. S. Sontag, Illness as Metaphor, dz. cyt. s. 41, 58.

87 Por. Z. Kubiak, Piękno i gorycz Europy. Dzieje Greków i Rzymian, Warszawa 2003, s. 81.

88 Tukidydes, Wojna peloponeska, tłum. K. Kumaniecki, Warszawa 1988, s. 117-118 (II, 54-55).

89 Nie tylko groźba choroby, lecz także rozboje we Florencji były powodem, dla którego bohaterowie Dekameronu uciekli na wieś. Por. K. Żaboklicki, dz. cyt., s. 73-74. Zasada „jedz, 
ta, szalejąca po całej Europie, jest również tematem finalnych scen powieści Sigrid Undset Krystyna córka Lavransa. Jeden z synów tytułowej bohaterki, Skule:

rzucił się w wir dzikiego życia, podobnie jak wielu młodych zrozpaczonych ludzi. „Kto się boi, tego śmierć nie minie” - mówili, głuszyli przeto trwogę piciem i ucztowaniem, grali i tańczyli, włóczyli się z kobietami. Nawet żony godnych mężów i młode córy najszlachetniejszych rodów uciekały w tym czasie z domu; w towarzystwie ulicznych ladacznic hałasowały i dokazywały po gospodach i w halach bractw wraz ze zdziczałymi mężczyznami. „Bóg niechaj im wybaczy” - myślała matka w duchu, ale serce jej zbyt było umęczone, by boleć nad tym bardzo ${ }^{90}$.

Podobny obraz kreśli Mann, wskazując, że epidemia w Wenecji wywołała bezprawie i bezkarność (s. 181). W czasie, gdy ulicami i kanałami miasta snuła się ohydna śmierć, przestały działać dobre obyczaje (s. 183), a zaczęły dominować popędy aspołeczne, zwykle ukryte (s. 181); w Wenecji zapanowały chaos i bezwstyd, znosząc dotychczasowe reguły ${ }^{91}$. Na ulicach pojawiali się pijani, zdarzały się też napady rabunkowe i morderstwa: „dwukrotnie już okazało się, że osoby, które rzekomo padły ofiarą zarazy, zostały przez własnych krewnych za pomocą trucizny sprzątnięte ze świata” (s. 181). Epidemia oznaczała zatem powrót do barbarzyństwa ${ }^{92}$, które Mann zdaje się wpisywać w przywołany wyżej dyskurs kolonialny: „ zawodowe hultajstwo przybrało dotkliwe i wybujałe formy, które tu były nieznane, zadomowione jedynie na Południu i na Wschodzie" (s. 181).

Przykładem cywilizacyjnego i obyczajowego rozprzężenia jest także los Aschenbacha, który wcześniej prowadził życie mieszczańskiego artysty, w Wenecji zaś porzucił dyscyplinę, uganiając się za nastolatkiem. W Monachium zachowanie takie byłoby skandalem, tymczasem w opanowanej przez indyjkką cholerę Wenecji nie zostało nawet zauważone; fryzjer zaś i gondolier, którzy rozpoznali sekret pisarza, nie byli zgorszeni (s. 173-174, 184). Przyczynami były nie tylko luźniejsze obyczaje panujące na lagunie, lecz także to, że epidemia usprawiedliwia zachowania niezgodne z przyjętymi normami. Z jednej bowiem strony groźba utraty życia nakazuje maksymalnie z niego korzystać, z drugiej - zło ma szansę pozostać bezkarne. W tej sytuacji jedynymi formami sprawiedliwości mogłyby być sąd boski i ewentualna kara w życiu przyszłym, bohaterowie noweli Manna jednak w świat nadprzyrodzony nie wierzą. Wprawdzie w noweli pojawiają się rekwizyty religijne (kaplica, cmentarz), ale nie pełnią one funkcji

pij, wesel się, bo jutro pomrzemy” nie była frazesem, lecz życiową dewizą. Por. W. Naphy, A. Spicer, dz. cyt., s. 27-28.

90 S. Undset, Krystyna córka Lavransa, t. 3: Krzyż, tłum. W. Kragen, Warszawa 1988, s. 398-399.

91 Por. M.V. Llosa, dz. cyt., s. 23.

92 Por. tamże. 
sakralnych; Aschenbach wszak to typ estety, wyznający kult sztuki, a nie Boga. $\mathrm{Z}$ tego powodu polska rodzina wydaje mu się egzotyczna, w niedzielę bowiem zamiast na plażę - idzie do kościoła (s. 172-173). Pisarz udaje się tam w ślad za Polakami tylko po to, aby napawać się widokiem Tadzia. Sam rytuał zresztą, pełen bizantyjskiego przepychu, budzi w pisarzu raczej niepokój zmysłów niż wzniosłe uczucia religijne (s. 173). Wiara nie jest też podstawą interpretacji zdarzeń opisanych w noweli; zaraza nie jest bowiem uważana za przejaw Bożego gniewu ${ }^{93}$, narrator zaś nie wspomina, aby księża modlili się o jej zakończenie $^{94}$. Nowela ukazuje zatem naturalistyczny model świata odczarowanego, w którym symbolika religijna przestała mieć znaczenie ${ }^{95}$; epidemia nie jest już sprawą religii, lecz medycyny, a nade wszystko - polityki.

Złożona i wielowarstwowa symbolika epidemii zawarta w noweli Manna może zostać odczytana w kategoriach duchowego kryzysu człowieka czy nawet całej kultury (zwłaszcza zachodniej, w której rozum zdaje się ulegać mrocznym, irracjonalnym siłom niekontrolowanych instynktów). Z perspektywy Śmierci $w$ Wenecji człowiek wydaje się bytem rozdartym między najwznioślejszymi dążeniami duchowymi a nieokiełznanymi popędami cielesnymi. Zgon Aschenbacha zdaje się sugerować, że rozwiązanie tego konfliktu jest niemożliwe, nawet twórca nie potrafi nadać swemu życiu harmonii i ładu. Niezależnie też od tego, czy źródłem kryzysu duchowego jest utrata dyscypliny wewnętrznej, organizującej codzienne życie, czy potężne uczucie, nad którym nie da się zapanować,

93 Zgodnie z mitologicznymi podaniami Greków Zeus rozgniewany na Agamemnona zesłał epidemię na jego wojsko. Por. Homer, Iliada, tłum. I. Wieniewski, Kraków 1984, s. 3, ks. I, w. 9-10. Początkowo podobnie postrzegał epidemię jeden z bohaterów Dżumy Camusa, ksiądz Paneloux. Por. A. Camus, Dżuma, tłum. J. Guze, Warszawa 1957, s. 93-100. Z czasem jednak, widząc cierpienie dziecka, tę wizję mściwego Boga porzucił; wkrótce po tym, jak zaangażował się w pomoc chorym, zmarł. Por. tamże, s. 217-230. Warto odnotować, że w języku polskim słowa „zaraza” czy „zarazić” pochodzą od słowa „raz”, pierwotnie oznaczającego uderzenie. Por. M. Ostaszewski, dz. cyt., s. 124.

94 Zwykle w czasach epidemii zanoszono modły do Boga o jej zakończenie; postawienie krzyża (na przykład dwuramiennego) bądź odprawienie mszy w miejscu zarazy miało powodować, że choroba ustępowała. Por. tamże, s. 128, 130. Epidemie bywały też przyczyną powrotu do dawnych, już zapomnianych bądź niepraktykowanych, kultów. Undset opisuje próbę złożenia w ofierze dziecka pogańskiej bogini Hel, odpowiedzialnej za sprowadzenie zarazy; dziecko przed śmiercią ratują zakonnice. Por. S. Undset, dz. cyt., s. 399-406.

$95 \mathrm{Z}$ pewnością aluzją o charakterze religijnym jest przywołana w noweli postać Sebastiana jako symbolu sztuki tworzonej przez Aschenbacha (s. 143). Możliwe, że mamy tu do czynienia z nawiązaniem do chrześcijańskiego męczennika, który - obok św. Rocha - uchodził za chroniącego ludzi przed chorobami i epidemiami. Por. W. Naphy, A. Spicer, dz. cyt., s. 28-30. Postać Sebastiana może też oznaczać homoerotyzm Aschenbacha, chrześcijański męczennik bowiem, odznaczający się dziewczęcą urodą, jest symbolem osób o niejednoznacznej seksualności. Por. P. Muratow, dz. cyt., s. 16. 
człowiek jawi się jako istota ułomna i chora; przejawami słabości są nie tylko skończoność (na śmierć nie ma lekarstwa), lecz także przyrodzony egoizm, nakazujący ludziom raczej troskę o własny interes niż solidarność z cierpiącymi. Wprawdzie groźba epidemii może budzić odruchy współczucia czy nawet heroizmu, jednak dominuje troska o siebie. Ponieważ w noweli Manna nie ma przykładów poświęcenia dla innych, są zaś przykłady kłamstwa, napadów rabunkowych i morderstw, można powiedzieć, że epidemia indyjskiej cholery demaskuje mroczne strony ludzkiej natury.

Utwór Manna wskazuje też, że nie da się jednoznacznie oddzielić rzeczywistości od fikcji; tak samo jak Wenecja stała się miejscem mitycznym, w którym umarł Aschenbach, w jakiejś mierze zastępując Wenecję realną, tak też epidemia istnieje tylko o tyle, o ile ludzie się o niej dowiedzą lub w nią uwierzą. Autor Śmierci w Wenecji dostrzegł, że w nowoczesnym i zglobalizowanym świecie głównym czynnikiem decydującym o ludzkim życiu jest polityka; ostatecznie bowiem nie tylko sposób radzenia sobie z epidemią, lecz nawet samo uznanie jej istnienia zależy od rządzących. Władza okazuje się tym samym główną siłą kreującą świat, decydującą o tym, które zjawiska będą uchodzić za rzeczywiste i prawdziwe, które zaś będą funkcjonować jako fikcja i nierzeczywistość tylko dlatego, że zostały skutecznie ukryte przed ogółem ludzi. Nawet śmierć może się w tej sytuacji okazać jedynie mityczną rzeczywistością literacką (Aschenbach) bądź elementem urzędowych statystyk lub niesprawdzonych pogłosek (bezimienne ofiary indyjskiej cholery w Wenecji).

\section{Bibliografia}

Ackroyd P., Wenecja. Biografia, tłum. T. Bieroń, Poznań 2015.

Adair G., The Real Tadzio: Thomas Mann's Death in Venice and the Boy, Who Inspired it, New York 2013.

Bordry M., Venise, ville morte ou "capitale di XIX siècle”? Regards vènitiens sur la disparition de la culture vènitienne, „Postures. Revue - critique littéraire” 2017, nr 26, http://revuepostures.com/fr/articles/bordry-26, dostęp: 27.08.2020.

Brandys K., Wywiad z Ballmeyerem [w:] Polska nowela wspótczesna, wyb. T. Bujnicki, J. Kajtoch, Kraków 1975, t. 1.

Camus A., Dżuma, tłum. J. Guze, Warszawa 1957.

Camus A., Rozważania o gilotynie, tłum. W. Szydłowska [w:] W. Szydłowska, Camus, Warszawa 2002.

Daniel-Rops H., Kościót wczesnego średniowiecza, przekład zbiorowy, Warszawa 1969.

Dostojewski F., Zbrodnia i kara, tłum. C. Jastrzębiec-Kozłowski, Warszawa 2019.

Ghosh A., The Horror of Contact: Understanding Cholera in Mann's "Death in Venice”, „Transtext(e)s Transcultures. Journal of Global Cultural Studies” 2017, nr 12. 
Girard R., Koziot ofiarny, tłum. M. Goszczyńska, Łódź 1987.

Grimmal P., Stownik mitologii greckiej i rzymskiej, tłum. M. Bronarska, B. Górska, A. Nikliborc, J. Sachse, O. Szarska, Wrocław 1990.

Hakselman M., Mikrokosmos rany. Granica u Kafki, „Teksty Drugie” 2013, nr 6. Härle G., Männerweiblichkeit: Zur Homosexualität bei Klaus und Thomas Mann, Frankfurt am Main 1988.

Herling-Grudziński G., Biata noc mitości. Opowieść teatralna [w:] tegoż, Dzieta zebrane, t. 6: Opowiadania wszystkie, vol. 2, Kraków 2017.

Herling-Grudziński G., Portret wenecki [w:] tegoż, Dzieła zebrane, t. 6: Opowiadania wszystkie, vol. 2, Kraków 2017.

Hiller K., Wo bleibt der homoerotische Roman? "Jahrbuch für sexuelle Zwischenstufen” 1914, nr 14 (3).

Homer, Iliada, tłum. I. Wieniewski, Kraków 1984.

Jankélélevitch V., La mort, Paris 2008.

Kafka F., Listy do Felicji i inne z lat 1912-1916, tłum. I. Krońska, t. 2, Warszawa 1976.

Kafka F., Listy do Mileny, tłum. F. Konopka, Kraków 1959.

Kafka F., Listy do rodziny, przyjaciót wydawców, wyb. P. Urbański, A. Urbańska, tłum. R. Urbański, Warszawa 2010.

Kant I., Antropologia w ujęciu pragmatycznym, tłum. E. Drzazgowska, P. Sosnowska, Warszawa 2005.

Kim T.-Z., Funkcje mityczne we wczesnych utworach Tomasza Manna, tłum. B. Tarnas [w:] Tomasz Mann w oczach krytyki światowej, wyb. A. Rogalski, Warszawa 1975.

Kitcher P., Deaths in Venice. The Cases of Gustav von Aschenbach, New York 2013.

Krüll M., Im Netz der Zauberer: Eine andere Geschichte der Familie Mann, Zurich 1991.

Kubiak Z., Piękno i gorycz Europy. Dzieje Greków i Rzymian, Warszawa 2003.

Lederer W., Love in Society: Thomas Mann's Early Stories [w:] A Companion to the Works of Thomas Mann, red. H. Lehnert, E. Wessell, Camden House 2004.

Lehnert H., Tomasza Manna wtasne interpretacje „śmierci w Wenecji”, tłum. A. Rogalski [w:] Tomasz Mann w oczach krytyki światowej, wyb. A. Rogalski, Warszawa 1975.

Leppmann W., Time and Place in "Death in Venice”, „The German Quarterly” 1975 , t. 48, nr 1.

Llosa M.V., Wotanie z otchtani [w:] M.V. Llosa, Prawda ktamstw. Eseje o literaturze, tłum. D. Walasek-Elbanowska, Poznań 1999.

Mann K., Moje nienapisane wspomnienia, przyg. E. Plessen, M. Mann, tłum. E. Bielicka, Warszawa 2007.

Mann T., Buddenbrookowie. Dzieje upadku rodziny, tłum. E. Librowiczowa, Warszawa 1956.

Mann T., Czarodziejska góra, t. 2, tłum. J. Łukowski, Warszawa 1972. 
Mann T., Jak powstat Doktor Faustus. Powieść o powieści, tłum. M. Kurecka, Warszawa 1960.

Mann T., Śmierć $w$ Wenecji, tłum. L. Staff [w:] tegoż, Śmierć $w$ Wenecji $i$ inne opowiadania, Wrocław 2003.

Mann T., Der Tod in Venedig [w:] tegoż, Erzählungen, Leipzig 1984.

McClain W.H., Wagnerian Overtones In „Der Tod in Venedig”, „Modern Language Notes" 1964, t. 79, nr 5.

Millington B., Kalendarium życia Wagnera, jego dziet i wydarzeń, tłum. R. Monita [w:] Wagner. Kompendium. Przewodnik po życiu i twórczości kompozytora, red. B. Millington, Kraków 2014.

Muratow P., Obrazy Wtoch, t. 1, tłum. P. Hertz, Warszawa 1972.

Naphy W., Spicer A., Czarna śmierć, tłum. A. Dębska, Warszawa 2004.

Ostaszewski M., Pamięć o epidemii cholery z 1893 roku we wsi Bagnówka pod Biatymstokiem, „Studia Podlaskie” 2015, t. 23.

Prus B., Lalka, t. 2, Warszawa 1966.

Rhode E., Psyche. Kult duszy i wiara $w$ nieśmiertelność u starożytnych Greków, wyb. H. Eckstein, tłum. J. Korpanty, Kęty 2007.

Sampson G., Historia literatury angielskiej w zarysie, Warszawa 1967.

Shookman E., Thomas Mann's Death in Venice: A Novella and Its Critics, Camden House 2003.

Shookman E., Thomas Mann's Death in Venice: A Reference Guide, Greenwood 2004.

Sontag S., AIDS and Its Metaphors [w:] tejże, Illness as Metaphor and AIDS and Its Metaphors, New York 1990.

Sontag S., Illness as Metaphor [w:] tejże, Illness as Metaphor and AIDS and Its Metaphors, New York 1990.

Szyrocki M., Literatura niemieckiego obszaru jezykowego [w:] Dzieje literatur europejskich, red. W. Floryan, Warszawa 1982, t. 2, cz. 1.

Tabet X., Venise dans la littérature française du XX siècle, „Laboratoire Italien” 2014, nr 15.

Tischner J., Myślenie wedtug wartości, Kraków 2005.

Tukidydes, Wojna peloponeska, tłum. K. Kumaniecki, Warszawa 1988.

Turner T., Venice Desired, Cambridge, Massachusetts 1992.

Undset S., Krystyna córka Lavransa, t. 3, Krzyż, tłum. W. Kragen, Warszawa 1988.

Vogt K.D., Vision and Revision: The Concept of Inspiration in Thomas Mann's Fiction, New York 1987.

Wolf E.M., A Case of Slightly Mistaken Identity: Gustav Mahler and Gustav Aschenbach, "Twentieth Century Literature” 1973, t. 19, nr 1.

Wołk M., Gtosy labiryntu. Od „Śmierci w Wenecji” do „Monizy Clavier”, Toruń 2009.

Żaboklicki K., Historia literatury wtoskiej, Warszawa 2019. 